\title{
Factors Influencing a Decision to Pursue a Degree in Aerospace Technology
}

\author{
R. Troy Allen. and Harry E. Minniear \\ Indiana State University
}

\begin{abstract}
This research was completed in order to identify factors that influence a student's decision-making process when deciding to enroll in the Aerospace Program at Indiana State University. Many research studies have identified factors that influence a student's decision process when choosing between universities. However, very little research dealt with the factors that influence the decision- making process of a student when selecting a collegiate aviation program. A convenience sampling was taken of 133 students who were completing a degree in aerospace administration or professional piloting. Nineteen different factors were ranked in descending order of mean value. Additionally an independent sample one-way analysis of variance was completed to identify any statistically significant differences between the two aerospace majors.
\end{abstract}

\section{INTRODUCTION}

Many state universities face a new financial reality where more is expected while less money is given. This pressure is being felt at the departmental level. With the ever-mounting pressure on faculty to maintain enrollment numbers, identifying ways in which educators could increase or at least maintain high enrollment numbers has become imperative. As found by Bowen, Carstenson and Hansen (1999), "Aviation faculties must be proactive and must maximize efforts to use all available tools to recruit aviation students" (p. 15).

Fund-raising efforts are but one measure used to stem the loss of capital. In addition, enrollment numbers are linked directly to revenue and are used to gauge the health of a program. Bowen, Carstenson and Hansen (1999), found that "For an academic program to successfully compete for resources today, it must keep its enrollments up by actively marketing its courses" (p. 18). Therefore, a program could be in danger of elimination for chronic low enrollment. For these reasons, there must be an awareness of the factors which influence a student's decision. There is a direct relationship between these factors and student enrollment.

There has been very little research completed identifying factors that influence a student's decision when selecting a collegiate aviation program. However, there has been considerable research performed that identified the factors that influenced a student's decision when choosing which university to attend. These factors have relevance to this study since some are synonymous with the ones that influence a student when determining what collegiate aviation program to attend. Therefore, it is relevant to include the university factors as they are closely interrelated and, in some cases, inseparable. They also provide additional justification for the need to complete this study.

Identifying these factors is important not only to an aviation department but also to the university since the success of a department is, in fact, the success of the university. Therefore, knowing what factors play a key role in a student's decision can be of great value to the aviation department.

\section{RESEARCH QUESTIONS}

1. Is there a significant difference between aviation students and the magnitude of influence the factors have on their decision to attend Indiana State University and pursue a degree in aerospace?

2. What factors are the most influential on a student's decision when deciding to enroll at Indiana State University and pursue a degree in aerospace?

\section{LITERATURE REVIEW}


Many factors influence a student's decision when deciding what university to attend. A study completed by Michael Paulsen (1990) found that, "Understanding these student choice behaviors are important so that institutions can enhance their enrollment planning activities and student marketing and recruitment activities" ( $p$. 1). Factors such as cost, academic reputation and teacher attributes (Canale. and Dunlap, 1996); high school counselor and friends (Johnson and Stewart, 1991); and family (Naylor, M., 1986) all have been identified as factors that influence a student's choice in selecting a university. This study found that many of these same factors play a role in the decision-making process a student uses to determine the collegiate aviation program in which to enroll.

A study by Johnson and Stewart (1991) found that a "particular academic program of interest to the student" is a major factor that influences a student in selecting one university over another (p. 84). The same was found to be true in research completed (Canale and Dunlap, 1996) which found "areas of study" offered ranked among the top factors in influencing a student to attend a university.

Research completed by Barnhart and Allen (2006), identified factors that influence a student to pursue an aviation career. The top three influential factors were flight in an aircraft, visit to an airport and watching an aviation movie. However, as the study did not investigate why a student choose a particular aviation program.

Therefore, the value of this research has been established in the literature. Although there is some commonality with university factors, this study has identified additional unique factors that influence a student's decision when considering a collegiate aviation program.

\section{LIMITATIONS}

- This study is limited to a sample of just under one-third of the student population in ISU's Aerospace Technology Program.

- This survey assumed that the students were honest when completing the survey document.

- The survey is not reflective of any distance education students.
- This study only surveyed students who choose ISU's aerospace program and did not survey those who reviewed the program and elected not to enroll.

- This survey assumed that each of the suggested factors influenced the students to some degree.

\section{INDIANA STATE UNIVERSITY}

Indiana State University (ISU) is located in the city of Terre Haute (pop. 57,000), approximately 70 miles west of Indianapolis. The university maintains a full time enrollment of approximately 11,000 students. The aerospace degree program at ISU is well established and has been in existence for over 40 years. During the last ten years, the Aerospace Technology program has averaged a total enrollment of between 250 to 300 students.

\section{Aerospace Faculty}

During the 2005-2006 academic school year the aerospace faculty consisted of two fulltime associate professors, six full time assistant professors, three adjunct professors, and two graduate assistants. One of the full-time associate professors also served as chairperson of the department. The student to full-time faculty member ratio would be approximately 35 to 1. Class sizes generally hover around 17-20 students with only one class exceeding 60 students.

The three adjunct professors and graduate assistants each taught one class, with the eight full time faculty members teaching the remainder of the classes. All full-time faculty members have varying degrees of general aviation flying experience. Three faculty members have military backgrounds and one has major airline experience. The approved terminal degree in the Aerospace Department at ISU is a master's degree in an aviation-related field of study. With respect to the eight full-time faculty, two have earned doctorial degrees, two are pursuing a doctorial degree, three have masters degrees, and one is pursuing a masters degree. In addition to standard university duties for faculty members, great emphasis is also placed upon research and scholarship activities.

\section{Admission Requirements}


Prospective students must have received a high school diploma. In addition, a ranking in the upper $40 \%$ of their high school graduation class is highly desired. Minimum SAT scores for admission are 900-1000. Previous flight time and college transfer credit hours can be applied towards degree completion requirements.

\section{Graduation Requirements}

Graduates of the ISU professional pilot program must complete 124 semester credit hours and obtain a Certified Flight Instructor Instrument certificate along with an aerobatic endorsement, tail wheel endorsement, and multi engine rating. Degree completion requirements for the aerospace administration degree require 124 semester credit hours.

\section{Facilities}

ISU has provided the Aerospace Department with state of the art facilities. All aviation classes are held in the twenty-four million dollar Myers Technology Center located on campus. The Technology Center is 9 years old and houses spacious classrooms with modern audiovisual equipment. The department has a weather laboratory that accommodates 30 students with separate desktop computers. The simulator lab has Frasca 141 and 142 simulators for basic training as well as two B-200 King Air simulators.

\section{Competition}

The nearest universities offering similar degree programs include Vincennes University (58 miles), Purdue University (90 miles), the University of Illinois (100 miles), and Southern Illinois University (170 miles).

\section{Cost}

Presently, the annual cost for tuition, room, board, books and incidental fees runs about $\$ 12,000$ per year for an in-state student. The flight fees for completion of all required certificates are estimated at $\$ 38,000$ over a fouryear period. The fees are based on a student's flying the most expensive aircraft in a category. This training results in a student obtaining a Certified Flight Instructor Instrument certificate with additional endorsements. Flight training is provided by two independent contractors. On average, students will graduate with approximately 350 hours of flight time.

\section{RESEARCH METHODOLOGY}

\section{Research Model}

The purpose of this study was to determine what factors influenced prospective students when choosing an aviation program. It utilized a survey instrument given to students currently enrolled in the undergraduate aerospace administration and flight degree program.

According to Leedy and Ormrod (2005), "Any single researcher is apt to have certain perspectives, assumptions, and theoretical biases-not to mention holes in his or her knowledge about the subject matter-that will limit how he or she approaches a research project" (p.34). For this reason, the research was completed by two researchers to take full advantage of collective expertise and create a more sound comprehensive study.

A convenience sample was obtained by surveying 133 students who are currently pursuing a degree in Aerospace Technology at Indiana State University. The survey was created to answer the question of what factors influence students when they are determining what collegiate aviation program in which to enroll.

In order to capture a sample that represented the entire population of students, the survey instrument was distributed to regularly scheduled aviation classes. A minimum of 100 surveys were desired for the research. In total 133 students completed surveys. The surveys were distributed and collected under strict adherence to all federal regulations and in compliance with the ISU Institutional Review Board.

\section{Survey Population}

All student participants in the survey were currently enrolled in one of the aviation degree majors at the university. Data was gathered by asking students to participate in the survey. Students ranged in age from 19 to 36 with the vast majority being recent high school graduates.

\section{Sources of Data}

Preliminary and background information for this project was found through traditional 
research methods. Data was collected with the aid of a survey and through a literature search that utilized the Internet and other library resources.

\section{Survey instrument}

The survey instrument, attached as Appendix A, was jointly created by the researchers. Student demographics were collected on aviation major, gender, class standing, and city of home residence. Nineteen factors were listed, and the students were asked to identify how influential each factor was in their decision to pursue an aviation degree at Indiana State University. The respondents were directed to rate on a scale of 1-7 how much a suggested factor influenced their decision. A "7" indicated that they immensely agreed while a " 1 " indicated that the factor played a less influential role in their decision making process.

\section{Instrument Validity and Reliability}

According to Gay and Airasian (2000) "Content validity is determined by expert judgment" (p. 164). The data collection device obtained content validity through review by aviation professors who had years of experience in collegiate teaching and research. The professors who reviewed the document were not part of the research team and had extensive experience meeting with students who were considering the ISU Aerospace Department program. The comments provided by the reviewers were incorporated into the survey instrument.

Reliability is the ability of a testing instrument to obtain the same results when it is administered multiple times. This survey instrument was only administered once to the subjects. Therefore, verifying reliability through multiple testing was not possible. McMillian and Schumacher (1997) state "The Cronbach Alpha is generally the most appropriate type of reliability for survey research and other questionnaires in which there is a range of possible answers for each item" (p. 242). In order to obtain reliability of the survey instrument, a Cronbach Alpha was completed which obtained an inter- rater reliability $\left(\mathrm{r}_{\mathrm{s}}=\right.$ .83 ). This indicates that $83 \%$ of variation is due to true variation. According to Fraenkel and
Wallen (2006), this falls within acceptable limits for research purposes.

\section{Treatment of the Data}

The data was gathered by a survey instrument that was used to answer the research questions. The surveys were managed under the institutional review board standards required by federal mandate.

\section{RESULTS}

This study was conducted to determine what factors influence a student's decisionmaking process when considering what collegiate aviation program to attend. SPSS was utilized to turn the survey data into meaningful statistical results.

In order to interpret the data, the mean values were rank ordered for professional pilot majors in Table 1 and for aviation administration majors in Table 2. Additionally, the standard deviation was listed to describe, "how spread out the scores are in the distribution" (Gravetter and Wallnau, 2007, p.123). In Table 3, the mean values and standard deviations for both majors have been combined.

An independent sample one-way analysis of variance (ANOVA) was completed with the alpha level set at .05 to determine which of the factors were significantly different between the two groups. The results of this statistical analysis are in Table 4 and were used to answer research question number one.

\section{DISCUSSION, ANALYSIS, AND RECOMMENDATIONS}

This study sought to find factors that influenced a student's decision to pursue a degree in aerospace at Indiana State University. A total of 133 students completed the survey consisting of aerospace administration majors ( $n$ $=26)$ and professional pilot majors $(n=107)$.

In order to determine which of the factors play a significant role in a student's decisionmaking process, the factors were rank ordered. The results of the mean rankings are found in tables 1 through 6 . In an effort to interpret the data derived from this research, the factors were grouped under four major headings. 
Table 1. Professional Pilot Rank Ordering of the Mean

\begin{tabular}{lrc}
\hline \multicolumn{1}{c}{ Factors } & Mean & Std. Deviation \\
\hline Speed to attain Flight Certificates & 5.0748 & 1.91174 \\
Tuition & 5.0187 & 1.69339 \\
Quality of Facilities & 4.9533 & 1.58640 \\
Personal Attention & 4.8505 & 1.85210 \\
Faculty to Student Ratio & 4.7290 & 1.78870 \\
Flight Simulators & 4.5794 & 1.66562 \\
Time to Completion of Degree & 4.4766 & 1.70098 \\
Flight Fees & 4.4393 & 1.70558 \\
Department Representative & 4.4393 & 1.68331 \\
ROI & 4.2430 & 1.85737 \\
Faculty Qualifications & 4.2336 & 1.76218 \\
Admittance Requirements & 4.1308 & 1.85352 \\
University Representative & 3.9533 & 1.58044 \\
Location of College & 3.8598 & 1.77747 \\
Financial Aid & 3.7570 & 1.94665 \\
Accept Previous Flight Time & 3.6822 & 2.48997 \\
Graduate Recommendation & 3.2897 & 2.05127 \\
Accept Previous College Credit & 3.1869 & 2.31537 \\
Parent & 2.9533 & 1.62749 \\
\hline
\end{tabular}

Table 2. Aerospace Administration Rank Ordering of the Mean

\begin{tabular}{lrc}
\hline \multicolumn{1}{c}{ Factors } & Mean & Std. Deviation \\
\hline Quality of the Facilities & 5.0226 & 1.59291 \\
Tuition & 4.9248 & 1.77791 \\
Personal Attention & 4.9098 & 1.78571 \\
Faculty to Student Ratio & 4.8271 & 1.76460 \\
Speed Flight Certificates & 4.6090 & 2.18061 \\
Department Representative & 4.3684 & 1.70771 \\
Time to Completion of Degree & 4.3383 & 1.74029 \\
Flight Simulators & 4.3233 & 1.86088 \\
Flight Fees & 4.2256 & 1.85708 \\
ROI & 4.1729 & 1.86885 \\
Faculty Qualifications & 4.1504 & 1.79434 \\
Admittance Requirements & 4.0226 & 1.87272 \\
University Representative & 3.8797 & 1.56688 \\
Location of College & 3.8421 & 1.84162 \\
Financial Aid & 3.7143 & 1.98697 \\
Accept Previous Flight Time & 3.3609 & 2.46902 \\
Accept Previous College Credit & 3.2406 & 2.31317 \\
Graduate Recommendation & 3.1955 & 2.08697 \\
Parent & 2.9398 & 1.70009 \\
\hline
\end{tabular}


Table 3. Combined Mean Ranking

\begin{tabular}{lcl}
\hline \multicolumn{1}{c}{ Factors } & Mean & Std. Deviation \\
\hline Quality of Facilities & 5.0226 & 1.59291 \\
Tuition & 4.9248 & 1.77791 \\
Personal Attention & 4.9098 & 1.78571 \\
Faculty to Student Ratio & 4.8271 & 1.76460 \\
Speed to Attain Flight Certificates & 4.6090 & 2.18061 \\
Department Representative & 4.3684 & 1.70771 \\
Time to Completion of Degree & 4.3383 & 1.74029 \\
Flight Simulators & 4.3233 & 1.86088 \\
Flight Fees & 4.2256 & 1.85708 \\
ROI & 4.1729 & 1.86885 \\
Faculty Qualifications & 4.1504 & 1.79434 \\
Admittance Requirements & 4.0226 & 1.87272 \\
University Representative & 3.8797 & 1.56688 \\
Location of College & 3.8421 & 1.84162 \\
Financial Aid & 3.7143 & 1.98697 \\
Accept Previous Flight Time & 3.3609 & 2.46902 \\
Accept Previous College Credit & 3.2406 & 2.31317 \\
Graduate Recommendation & 3.1955 & 2.08697 \\
Parent & 2.9398 & 1.70009 \\
\hline
\end{tabular}

Table 4. ANOVA Statistically Significant Factors

\begin{tabular}{|c|c|c|c|c|c|}
\hline \multicolumn{2}{|l|}{ Factors } & \multirow{2}{*}{$\frac{\text { Sum of Squares }}{24.993}$} & \multirow{2}{*}{$\frac{\text { Mean Square }}{24.993}$} & \multirow{2}{*}{$\frac{F}{7.610}$} & \multirow{2}{*}{$\begin{array}{l}\text { Sig. } \\
.007\end{array}$} \\
\hline Flight Fees & Between Groups & & & & \\
\hline & Within Groups & 430.240 & 3.284 & & \\
\hline & Total & 455.233 & & & \\
\hline \multirow[t]{3}{*}{ Flight Simulators } & Between Groups & 35.908 & 35.908 & 11.168 & .001 \\
\hline & Within Groups & 421.190 & 3.215 & & \\
\hline & Total & 457.098 & & & \\
\hline \multirow[t]{3}{*}{$\begin{array}{l}\text { Speed to Obtain Flight } \\
\text { Certificates }\end{array}$} & Between Groups & 118.729 & 118.729 & 30.561 & .000 \\
\hline & Within Groups & 508.940 & 3.885 & & \\
\hline & Total & 627.669 & & & \\
\hline \multirow[t]{3}{*}{$\begin{array}{l}\text { Acceptance of Previous } \\
\text { Flight Time }\end{array}$} & Between Groups & 56.519 & 56.519 & 9.896 & .002 \\
\hline & Within Groups & 748.158 & 5.711 & & \\
\hline & Total & 804.677 & & & \\
\hline
\end{tabular}

Table 5. Mean Ranking of Groupings

\begin{tabular}{ll}
\hline Grouping & Mean \\
\hline Shared Department/University Factors & 4.36 \\
Flight Related Factors & 4.13 \\
Program Attribute Factors & 3.91 \\
Social Interaction Factors & 3.86
\end{tabular}




\section{Social Interaction Factors}

Factors such as Personal Attention $(\mathrm{M}=$ 4.91, S.D. $=1.79$ ), Department Representative $(\mathrm{M}=4.37, \quad$ S.D $=2.18)$, University Representative $(\mathrm{M}=3.88$, S.D. $=1.57)$, Graduate Recommendation $(\mathrm{M}=3.20$, S.D. $=$ 2.09), and Parent $(\mathrm{M}=2.94$, S.D. $=1.70)$, all deal with the exchange of information through social interaction. A significant attribute of this group is that efforts can be made in this area without significant capital investments. Cost is always a consideration, and therefore, if changes could be made to a program that would have a positive impact on enrollments with no monetary commitment they should be given serious consideration. These factors should be reviewed to assure that best practices are being used. For those social interactions that are within the control of departmental faculty the factors listed in "program attributes" should be highlighted during the interaction.

Obviously, these factors illustrate that the perception by others is paramount to a healthy aviation program. Proper interpersonal skills are a necessity when interacting with parents and alumni. Additionally, today's students become tomorrow's alumni and should be treated with respect while in a program so that a cordial relationship will be established.

\section{Flight Related Factors}

Understandably, some of the factors listed could be influential with one of the aerospace majors while having less significance on the other. An independent sample one-way analysis of variance was completed using Statistical Package for the Social Sciences (SPSS). This statistical procedure has the ability to determine differences in the means that are not a result of chance but are true differences (Gravetter \& Wallnau, 2007).

The ANOVA found statistical significance exists between the mean values reported on professional pilots and aerospace administration majors in the following factors: Flight Fees $F(1$, $19)=7.61, p=.007$, Flight Simulators $F(1,19)=$ $11.17, p=.001$, Speed to Obtain Flight Certificates $F(1,19)=30.56, p=.000$ and Acceptance of Previous Flight Time $F(1,19)=$ $9.89, p=.002$. Thus noted, all of these factors can be grouped under flying, and as expected, the professional pilot majors reported these as more influential than the aerospace majors.

Interestingly, the aerospace majors indicated that these factors were influential to any degree. However, a portion of the aerospace administration majors were initially professional pilot majors who decided to change majors for a variety of reasons. Thus, when they recall what influenced them initially to pursue a degree at ISU, these factors were influential. Many of these factors ranked very high on mean values. They should be covered in detail in any attempts to sell the program one-on-one or when utilizing mass marketing methods.

\section{Shared Department/University Factors}

When referencing Table 5 it can be seen that this grouping has the highest combined mean value of all of the groups. Factors in rank order under this heading were Quality of Facilities $(\mathrm{M}=5.02$, S.D. $=1.59)$, Tuition $(\mathrm{M}=$ 4.93, S.D. $=1.78)$, Faculty to Student Ratio (M $=4.82$, S.D. 1.76), Time to Completion of Degree $(\mathrm{M}=4.34$, S.D. $=1.74)$, Faculty Qualifications $(\mathrm{M}=4.15, \quad$ S.D. $=1.79)$, Admittance Requirements $(\mathrm{M}=4.02$, S.D. 1.87 and Acceptance of Previous College Credit ( $\mathrm{M}=$ 3.24, S.D. $=2.31$ ).

These factors require a combined effort by the university and department in order to affect change. Nonetheless, attempts should be made to increase their positive influence on students. These attributes could be highlighted during any social interaction with outside groups in order to make a positive impact on enrollments. Potential students and parents should be informed of these program aspects.

\section{Program Attributes Factors}

Other factors on which data were collected included Return on Investment $(\mathrm{M}=4.17$, S.D. =1.87), Location of College $(\mathrm{M}=3.84$, S.D. $=$ 1.84) and Financial Aid ( $M=3.71$, S.D. 1.99). These factors are very difficult for a department to change. For example, college location is something over which departments have no control. However, highlighting the positive attributes of living in a certain community could influence a student's decision in a positive manner when considering the program. Additionally, explaining their return on investment and potential financial aid could 
impart a positive contribution to enrollments. Educating students on these factors would have very little associated cost, and they should be included in any program overview given to a potential student or in departmental literature.

\section{Additional Factors Listed by Respondents}

Question number 20 on the survey instrument asked the respondents to list any additional factors that played a significant role in their decision. The only comment that was voiced by multiple respondents was that the program offered them the ability to pick between two flight contractors in order to obtain their flight certificates and ratings. This was seen as a positive attribute.

\section{CONCLUSIONS}

This research was born out of a need to determine why a student decided to attend the Indiana State University Aviation Program. Recently, there has been a decline in enrollments in the ISU aerospace program. However, this does not mean that steps cannot be taken to reverse the trend. The authors sought to identify and quantify those factors that were influential in the decision-making process. That objective has been accomplished.

With respect to research question one:

Is there a significant difference between aviation students and the magnitude of influence the factors have on their decision to attend Indiana State University and pursue a degree in aerospace?

An independent sample one-way ANOVA was completed at the .05 level to answer this question. Statistical significance was found to exist. Those factors that were significant are all listed in Table 4.

With respect to research question two:

What factors are the most influential on a student's decision when deciding to enroll at Indiana State University and pursue a degree in aerospace?

In order to answer this question the mean value of the entire sample was calculated on each factor. The factors were then rank ordered on a mean value. It was determined that some factors are more influential in the students' decision-making process. This ranking is listed in Table 5

It should be noted that this study found how these 19 factors influenced a student's decision. It did not explore the 19 factors full ability to influence a student's decision. Consider that parents ranked as the least influential out of all of the factors. Should one assume that parents do not have the ability to influence a student? It could be that the Aerospace Department has not fully utilized a factor to influence enrollments in a positive manner. Therefore, it needs to be stressed that this study did not determine the potential of a factor to influence a student's decision.

The information contained in this study may be beneficial in affecting enrollments in a positive manner. A follow-up study could be completed to determine how to use the results of this research to accomplish that goal. 


\section{REFERENCES}

Allen, R.T., \& Barnhart, R.K. (2006). Influencing factors in degree selection for aviation majors at Indiana State University. The Journal of Aviation/Aerospace Education and Research, 15(3), 23-30.

Bowen, B., Carstensen, L., \& Hansen, F. (1999). Recruiting from within: Action-Oriented research solutions to internal student recruitment in collegiate aviation education. Journal of Air Transportation World Wide, 4(1), 14-25.

Canale, J. \&. Dunlap, L. (1996). The Relative Importance of Various College Characteristics to Students in Influencing Their Choices of a College. College Student Journal, 30(2), 275-403.

Fraenkel, J.R.. \& Wallen, N.E. (2006). How to design and evaluate research in education (6 ${ }^{\text {th }}$ ed.). New York: McGraw Hill.

Gay, L.R., \& Airasian, P. (2000). Educational research: competencies for analysis and application (6 ${ }^{\text {th }}$ ed.). New Jersey: Prentice-Hall.

Gravetter, F.J., \&. Wallnau, L.B. (2007). Statistics for the behavioral sciences (6 $6^{\text {th }}$ ed.). Belmont: The Thomson Corporation.

Johnson, R., \&. Stewart., N.R. (1991). Counselor impact on college choice. School Counselor, 39(2), 84-91.

Leedy, P.D., \& Ormrod J.E. (2005). Practical research. Pearson: Merrill Prentice Hall.

McMillan, J.H., \&, Schumacher, S. (1997). Research in education (4 ${ }^{\text {th }}$ ed.). New York: Addison-Wesley.

Naylor, M. (1986). Family influences on employment and education. ERIC Digest no. 56. Columbus: ERIC Clearinghouse on Adult, Career, and Vocational Education, The National Center for Research in Vocational Education, The Ohio State University, ED 272702.

Paulsen, M. (1990). College Choice: Understanding student enrollment behavior. ASHE-ERIC Higher Education Report No. 6. Washington, DC: George Washington University, School of Education and Human Development. 


\section{Appendix A}

Factors Influencing a Decision to Pursue a Degree in Aerospace Technology at Indiana State University

The items below list factors that may have influenced your decision to pursue a degree in aerospace technology at Indiana State University. Please read each item and indicate the degree to which you believe the stated factor influenced your decision to pursue a degree in aerospace at Indiana State University. If the factor listed influenced you immensely, circle "7."If the factor listed did not influence you at all, circle "1." If the degree to which you believe the factor listed falls somewhere between "7" and "1" for you, circle the number that best represents the degree to which that factor assisted you in making your decision to pursue an aviation technology degree.

My decision to pursue an Aerospace Technology degree at Indiana State University was influenced by ...

\section{IMMENSELY}

NOT AT ALL

1. Cost of tuition

2. Location of home residence to the college

3. Parental influence

4. Cost of flight fees

5. Reputation of University

6. Reputation of Aerospace Department

8. Personal attention by faculty member

9. Recommendations by graduates

10. Quality of facilities

11. Flight simulators

12. University admittance requirements

13. Return on the investment

14. Availability of financial aid

15. Time to completion of degree

16. Time to obtain flight certificates

17. Acceptance of previous flight time

18. Acceptance of previous credits

19. Faculty qualifications

$\begin{array}{lll}7 & 6 & 5 \\ 7 & 6 & 5 \\ 7 & 6 & 5 \\ 7 & 6 & 5 \\ 7 & 6 & 5 \\ 7 & 6 & 5 \\ 7 & 6 & 5 \\ 7 & 6 & 5 \\ 7 & 6 & 5 \\ 7 & 6 & 5 \\ 7 & 6 & 5 \\ 7 & 6 & 5 \\ 7 & 6 & 5 \\ 7 & 6 & 5 \\ 7 & 6 & 5 \\ 7 & 6 & 5 \\ 7 & 6 & 5 \\ 7 & 6 & 5 \\ 7 & 6 & 5\end{array}$

20. Other 